\title{
South America's biophysical involvement in international trade: the physical trade balances of Argentina, Bolivia, and Brazil in the light of ecologically unequal exchange
}

\author{
Christian Dorninger ${ }^{\mathrm{a}, 1}$ \\ Nina Eisenmenger ${ }^{\mathrm{b}}$ \\ ${ }^{a}$ Leuphana University of Lüneburg, Germany \\ ${ }^{\mathrm{b}}$ Alpen-Adria University, Austria
}

\begin{abstract}
International trade is becoming increasingly important in the strategies of industrialized economies ('core' countries) to meet their physical needs and maintain their social metabolism. Less industrialized ('non-core') countries, in particular those with low population densities such as countries in South America, provide a large share of the natural resources currently being used by the 'core' countries. This article analyzes the relations of biophysical exchange of Argentina, Bolivia, and Brazil with global 'core' and 'non-core' countries in order to add to a discussion of possible relations of different national economic policies, such as import substituting industrialization or neoliberal adjustment, on the countries' physical trade balances (PTBs). By that we will provide a biophysical reading of ecologically unequal exchange; by investigating whether there is a physical net trade flow from 'non-core' to 'core' countries, whether primary products dominate exports of 'non-core' countries in exchange for processed products from 'core' countries, and whether the notion of unfavorable mass-to-price relation for the trading 'non-core' countries applies (Hornborg 2012; Martinez-Alier 2007). The magnitudes, type of material, stage of processing and monetary value of the traded goods are analyzed for the time period from 1962 to 2011. The evaluations have been carried out for trade relations with the 'core' and the 'non-core' countries separately. Additionally, in order to trace the so-called China Effect, which led to the period of new extractivism, the quantities exported to China are shown separately. The results indicate that the three countries examined are net exporters of physical quantities. The physical involvement in 'core'- and 'non-core'-related international trade differs greatly, but at the same time the relative importance of the 'core' as trading partner has decreased steadily over the five decades. Still, 'core'related trade involves the most unfavorable mass-to-price relation. These conditions, i.e. high importance of unprocessed export commodities, low average unit prices, and an unfavorable monetary trade balance (MTB), reveal many characteristics of an ecologically unequal exchange. This is especially true for Argentina and Brazil. Due to its lower economic performance and limited involvement in international trade, Bolivia to some extent represents an exception.
\end{abstract}

Keywords: Ecologically unequal exchange, physical trade balance, South America, Argentina, Bolivia, Brazil.

\section{Résumé}

Le commerce international devient de plus en plus important pour les économies industrialisées afin de satisfaire leurs besoins matériels et maintenir leur fonctionnement social. Les pays en voie de développement, en particulier ceux qui présentent une faible densité de population comme l’Amérique du Sud, fournissent une

\footnotetext{
${ }^{1}$ Christian Dorninger, PhD candidate, Faculty of Sustainability, Leuphana University of Lüneburg, Germany. E-mail: christian.dorninger "at" leuphana.de. This article is based on his Masters thesis in Development Studies, University of Vienna, which was supervised by Dr. Nina Eisenmenger, Post-Doc. Assistant Professor, Institute of Social Ecology, IFF Vienna, Alpen-Adria University Klagenfurt, Austria. Thankyou to anonymous referees. This is the fifth article in Alf Hornborg and Joan Martinez-Alier (eds.) 2016. "Ecologically unequal exchange and ecological debt", Special Section of the Journal of Political Ecology 23:328-491.
} 
grande partie des ressources naturelles nécessaires aux pays industrialisés qui jouent un rôle «central». Cette contribution se rapporte aux relations d'échange biophysiques de l'Argentine, de la Bolivie et du Brésil avec les pays mondiaux de rôle «central» et «périphériques». Afin de comprendre les conséquences du soi-disant «Impact chinois» qui mène à la période du «nouvel extractivism» les exportations vers la Chine sont présentées séparément. L'objectif de la recherche est d'examiner l'influence de différentes orientations nationales du développement comme les imports qui substituent l'industrialisation ou le réajustement néolibéral sur les balances commerciales physiques des pays et de prouver la supposition de l'échange inégal écologique. Pour cette raison, la dimension, le type de matériau, le stade du traitement ainsi que la valeur monétaire des marchandises échangées sont analysés pour la période allant de 1962 à 2011. Les évaluations étaient faites séparément pour le commerce rapporté au centre et le commerce rapporté à la périphérie. Les résultats indiquent que les trois pays examinés sont des exportateurs nets de quantités physiques. Cependant, il y a une grande différence dans leur participation physique au commerce international du centre et de la périphérie. L'importance relative du centre comme partenaire commercial baisse de façon continue alors que le commercial rapporté au centre implique la masse la plus inégale à la relation du prix. Compte tenu du stade du traitement des marchandises exportées, des prix moyens à l'unité et de la balance commercial monétaire, beaucoup de caractéristiques d'un échange inégal écologique sont révélées. C'est particulièrement vrai pour l'Argentine et le Brésil. Dans une certaine mesure, la Bolivie représente en raison de sa faible performance économique et de sa participation limitée au commercial international une exception.

Mots-clés: Échange inégal écologique, balance commerciale physique, Amérique du Sud, Argentine, Bolivie, Brésil.

\section{Resumen}

El comercio internacional se está haciendo cada vez más importante para economías industrializadas para cumplir sus necesidades físicas y mantener su metabolismo social. Países en desarrollo, en especial los países de baja densidad de población como América del Sur, proveen un gran parte de recursos naturales necesitados por los países industrializados. Esta contribución concierne a las relaciones biofísicas de intercambio de Argentina, Bolivia, Brasil con los países globales 'centrales' y 'no centrales'. Para repasar los resultados del efecto-chino, que lleva a la época del nuevo extractivismo, las cantidades de exportación a China se muestran por separado. La investigación tiene como objetivo examinar la influencia de orientaciones nacionales de desarrollo diferentes - como la industrialización por sustitución de las importaciones o ajustes neoliberales - a las balanzas comerciales físicas de los países y además probar suposiciones del intercambio ecológico desigual. Por lo mismo, la magnitud, el tipo de material, la etapa del procesamiento así como el valor monetario de las mercancías intercambiadas son analizados para el periodo de referencia 1962-2011. Las evaluaciones habían sido realizadas por el comercio 'central' y 'no central' por separado. Los resultados muestran que los tres países examinados son exportadores netos de cantidades físicas. Sin embargo, su implicación física en el comercio internacional relacionado con 'central' y 'no central' varía mucho. La importancia relativa del centro como socio comercial había disminuido de manera constante aunque el comercio con el 'centro' sigue suponiendo la cantidad más desigual a la relación precio. Teniendo en cuenta la etapa del procesamiento de productos básicos de exportación, los precios unitarios medio y la balanza comercial monetaria, muchas características de un intercambio ecológico desigual son visibles. Esto es especialmente cierto para Argentina y Brasil. Debido a sus escasos resultados económicos y su participación limitada en el comercio internacional Bolivia constituye una excepción en cierta medida.

Palabras clave: Intercambio ecológico desigual, balanza comercial física, América del Sur, Argentina, Bolivia, Brasil.

\section{Introduction}

Economies rely on material and energy inputs in order to sustain and expand their socioeconomic structures. Industrialized ('core') countries typically use structures with greater physical mass and thus maintain a larger material and energy throughput than less industrialized ('non-core') countries. To meet their physical needs, 'core' countries increasingly depend on international trade and in particular on imports. These imports often come from 'non-core' countries, resulting in a net material inflow to 'core' countries and thus a significant imbalance in physical trade flows between 'core' and 'non-core' regions (Adriaanse et al. 1997; Dittrich and Bringezu 2010; Giljum and Eisenmenger 2004; Hornborg 2010, 2012; Martinez-Alier 2007; Matthews et al. 2000; Schütz, Moll and Bringezu 2004; Wiedmann et al. 2013). 
This article investigates international trade from a biophysical perspective, in particular biophysical exchange relationships between South America and 'core' and 'non-core' countries on other continents. The 'core' consists of the current OECD member countries, with the exception of Chile, Israel, Mexico and Turkey. ${ }^{2}$ Three countries have been chosen to represent South America: Argentina, Bolivia, and Brazil. These three neighboring countries together cover more than two-thirds of the South American land area and 63\% of the South American population. International trade is examined using data from material flow accounts and the physical trade balance (PTB) is calculated for each country. The particular focus lies on the volume and composition of physical trade flows and the respective monetary value derived through trade. In this way, indications of ecologically unequal exchange are explored; i.e. physical net trade flows from 'non-core' to 'core' countries, the domination of primary products in the exports schemes of 'non-core' countries in exchange for processed products from 'core' countries, and the notion of unfavorable mass-to-price relation for the trading 'non-core' countries (Hornborg 2012; Martinez-Alier 2007). The physical trade relations are put into context by considering them in relation to national economic policies and programs, such as import substituting industrialization (ISI) or structural adjustment programs (SAPs).

The foundations of the concept of unequal exchange were formulated in the 1970s and 1980s as part of World Systems Theory and Dependency Theory (Frank 1966; Wallerstein 1974, 1980, 1989). The expansion towards its physical representation, i.e. ecologically unequal exchange, has been discussed in depth by Joan Martinez-Alier (1987, 2002, 2007), Alf Hornborg (1998, 2007, 2010, 2012) and Stephen G. Bunker (1985). The concept suggests that poorer world regions (here denoted as 'non-core' countries) generally provide resource-intensive, primary goods that are also labor-intensive, involving low-skilled labor, characterized by high homogeneity and thus exposed to high international competition and, as an effect, only generate low economic income. Primary goods are exported to more affluent economies ('core' countries) in exchange for manufactured goods and services. The latter are characterized by high-tech, capital-intensive production generating high economic value. Unequal exchange thus maintains a net transfer of resources and money to the 'core', which can sustain high metabolic rates and a continuous saving of time and space (through a net import of materials and energy) while shifting environmental burdens to peripheral 'non-core' countries (Hornborg 2012; Martinez-Alier 2007; Muradian and Martinez-Alier 2001).

Following the criteria of these authors, an ecologically unequal exchange cannot be entirely captured by conventional economic studies of exchange, but requires the consideration of biophysical aspects of production, transport, and consumption. Complementing a purely money-focused view on trade with an ecological view widens the perspective and offers important additional information. Hornborg (2012) and Martinez-Alier (2007) both consider the Second Law of Thermodynamics as essential to the concept. When applied to the comparison of price and mass development in the value chain of a product, the Second Law of Thermodynamics implies that in a production chain entropy is irreversibly increased, whereas the exergy of the original inputs decreases at the same time. The loss of initial mass and productive potential is accompanied by an increase in prices. This leads Hornborg (2012) to the conclusion that industrial centers (like industrialized countries and cities) gain access to ever more available energy from their peripheries by importing mainly primary goods, since they process those goods and in return sell less exergy at a higher price. In this respect, modern technology has a redistributive function with regard to time and space in the world-system and thus enables ecologically unequal exchange. Furthermore, Martinez-Alier (2002: 214) emphasizes that export prices of primary goods do not take into account local externalities, which involve costs and impacts caused by these exports. The exporting regions' lack of political power and the absence of an alternative, such as exporting goods with lower local impacts and at a higher stage of processing, fuel ecologically unequal exchange. For empirical analyses of ecologically unequal exchange, Hornborg suggests material flow accounting tools and explicitly mentions physical trade balances as possible indicators (Hornborg 2010: 41, 2012: 107).

\footnotetext{
${ }^{2}$ These countries joined the OECD rather late and were, during most of the time period investigated, not part of the OECD (this is the case for Chile and Israel; www.oecd.org), or they currently have the lowest GDP per capita of the OECD community (Mexico and Turkey; www.imf.org). Countries that are currently members of the EU and the OECD were classified as 'core' states.
} 
Building on existing work that discusses ecologically unequal exchange in physical terms (e.g., Giljum and Eisenmenger 2004; Jorgensen and Clark 2009; Rice 2007) this article provides further insight into the patterns of international trade in South American countries. First, we provide an introduction to the method and data used; second, we present a brief overview of macroeconomic development in the countries examined in order to relate the results to their political-economic background; third, the analytical section provides the actual results, evaluations, and interpretations; and finally, the concluding section will relate the results to the hypotheses presented in the introduction.

\section{Methods and data}

The empirical analyses in this article are based on data from economy-wide material flow accounts (ew-MFA), which are part of the broader environmental accounting family (EUROSTAT 2012; OECD 2008; United Nations 2014). These physical accounts aim at monitoring socio-economic activities and their effects (pressures and impacts) on the natural environment by providing a biophysical complement to economic accounts. Economy-wide material flow accounts comprise all material flows entering or leaving an economy from or to the natural environment (i.e. either domestic extraction or wastes and emissions) or from or to other countries (imports or exports). Material flows are commonly aggregated into five main categories (biomass, fossil fuels, metals, non-metallic minerals, and other products) and the unit of measurement is metric tons. Accounting methods have been standardized in the past two decades (EUROSTAT 2012; Fischer-Kowalski et al. 2011) and MFA is part of statistical reporting in the EU (European Union 2011). The most prominent indicator in MFA is domestic material consumption (DMC) which denotes all materials extracted within a nation's boundaries plus imports and minus exports. In most countries, DMC is still mainly composed of domestic extraction (DE); however, in some countries trade has great importance (e.g. Weisz and Schandl 2008).

\section{The physical trade balance}

In this article we use the physical trade balance (PTB) as an indicator that may be used as a proxy for ecologically unequal exchange. The PTB measures material flows calculated as the subtraction of exports from imports, and thus represents the net trade flows of a country. A negative PTB implies a net export whereas a positive PTB indicates a net import of physical resources. The balance thus shows if and to what extent a country is either a net provider of physical goods to the world market or whether it depends on material imports from abroad. A growing number of countries are net-importers and thus rely on international trade in order to meet their socio-economic needs for physical goods. Physical exchange relations across national boundaries are continuing to increase in volume and are becoming more relevant than ever (Dittrich and Bringezu 2010).

As already mentioned, the PTB classifies the traded products in terms of five categories of materials: (1) biomass and biomass products; (2) fossil energy carriers, primary and processed, (3) metal ores and concentrates, and processed metals; (4) non-metallic minerals, primary and processed; and (5) other products. ${ }^{3}$ The analyses in this article follow the standard categorization of traded goods proposed by EUROSTAT (2012).

\section{Data sources and estimation procedures}

The main database for calculating PTBs is the United Nations Commodity Trade Statistics Database (http://comtrade.un.org/db). The UN Comtrade database provides records of internationally traded physical quantities (annual imports and exports) of commodities in metric tons and their corresponding monetary value in US\$ as reported by national statistical authorities. It is the most comprehensive collection of international trade flows available and covers trade statistics from 1962 onwards. In addition to the UN trade data, two

\footnotetext{
${ }^{3}$ The group 'other products' comprises all traded goods for which no main material can be identified, such as musical instruments or artworks.
} 
other sources were used for cross-checking: first, trade data provided by the UN Food and Agricultural Organization (FAOSTAT, http://faostat.fao.org) and second, data from the UN International Energy Agency (IEA, http://www.iea.org/statistics). In the case of missing or uncertain data, two methods have been applied: first, missing data were extrapolated when there was a more or less linear trend by calculating the mean between the adjacent years; second, physical data could be estimated by using the corresponding monetary value (US\$) and an average price calculated from years where both physical and monetary values were reported. We compiled physical trade data in time series for the years 1962 to 2011. In addition to the physical trade data, we also used the monetary values reported in the UN Comtrade database to calculate unit prices and monetary trade balances (MTB). ${ }^{4}$

\section{Deeper analysis: specific trading partners and stages of processing}

In MFA, imports and exports are usually calculated at a very high level of aggregation with no differentiation according to where the traded goods are coming from or delivered to and with no consideration of their stage of processing. However, for an analysis of specific trade relations, more detail is needed. In our database, we therefore expanded the standard MFA data structure in two directions: we sorted the trading partners into two groups, viz. 'core' and 'non-core' countries. This way we are able to address the occurrence of ecologically unequal exchange, by considering whether a 'non-core' country is particularly oriented towards the 'core' or linked to other 'non-core' countries. In addition, we also differentiate traded goods according to their stage of processing. We have used the detailed classification of products in the UN Comtrade database to distinguish between primary and secondary or finished goods. These data allow us to discuss the influence of a country's specialization on its economic development.

\section{Macroeconomic structures: Argentina, Bolivia, and Brazil}

In order to achieve valid conclusions, the consideration of historical developments is indispensable. After attaining national independence in the early $19^{\text {th }}$ century, South American countries were characterized by growth based on exports of primary goods and an outward-looking orientation, which perpetuated patterns installed during colonization (Cardoso and Helwege 1992). This export-led growth implied dependency and limited conditions for development. Consequently, a common goal that came to be pursued in different ways by these countries was the achievement of greater independence from international price volatilities and demand fluctuations deriving from an erratic world economy. In response to the Great Depression in South America, this new development pathway had already been adopted in the 1930s as 'import substituting industrialization' (ISI), with the aim of using national resources to supply national needs and producing and exporting high-value manufactured goods. The theoretical foundations of ISI in South America were formulated by Raúl Prebisch (1949) and Celso Furtado (2007). Commonly applied tools were import quotas and tariffs, overvalued exchange rates, and direct government investment in key industries (Bulmer-Thomas 1994; Cardoso and Helwege 1992; Scott 2011; Weaver 2000).

But proponents of the ISI model increasingly faced the serious dilemma of inefficient and uncompetitive production. Tariff-protected companies produced relatively expensive and low-quality goods for the domestic market, and most firms were unable to compete on the international market. Furthermore, the domestic market was often too small and had too little purchasing power to be able to generate economies of scale. Inefficient production and lack of exports, coupled with the need for specific imports, resulted in chronic balance of payment deficits. As a consequence, the ISI strategy contributed - together with external

\footnotetext{
${ }^{4}$ Note that the monetary trade balance, unlike the PTB, is calculated by subtracting imports from exports. This reflects the different directions in which physical and monetary flows move: an import represents physical mass entering a country but at the same time monetary value leaving the country; the converse applies to exports. The net trade balance considers both monetary and physical terms: a positive trade balance represents a surplus and thus more materials and more monetary value entering the country. A country with a negative trade balance, on the other hand, is characterized by a trade deficit, and thus money and mass flows out of the country.
} 
interventions of foreign governments, international organizations and corporations - to a significant downturn in these economies from the late 1960s onwards (Bulmer-Thomas 1994).

In 1982, Latin America slid into a severe debt crisis. Debt services, domestic capital flight, and deteriorating terms of trade, as well as higher interest rates on foreign loans, meant South American governments were confronted with enormous fiscal problems (Weaver 2000: $169 \mathrm{ff}$.). Subsequently, international organizations from the World Bank group, like the IMF, came to exercise more and more influence, for example through the conditionality of loans and structural adjustment programs (SAPs). The countries were susceptible to IMF requirements, whose loans were conditional on austerity policies, a smaller state sector and other neoliberal economic measures, including the promotion of free trade and export. ${ }^{5}$ In response to several adjustment programs and the pressure of rising debts, the republics finally reverted to prioritizing export production of primary goods. The emerging consensus among creditors became known as the 'Washington Consensus' (Babb 2013: 270 ff.; Bulmer-Thomas 1994: 366 ff.; Weaver 2000: 133). The hope of many countries in the periphery that they could catch up with development in the core, by applying an inward-looking strategy, was gone. Rapidly increasing debts and debt servicing burdens compelled South American countries to abandon their chosen pathway and to enter into a new age of neoliberalism and exportled growth (Wallerstein 2000).

After two decades of conforming to neoliberal demands, the beginning of the new millennium once again marked a broad turning point in South America towards a post-neoliberal and post-Washington Consensus policy. A shift in power to leftist parties took place in many countries. Recent studies (Hogenboom 2012; Veltmeyer 2013) suggest that despite political change, the structures of the extractive economy were not abandoned - indeed, quite the contrary. Newly elected leftists, like Morales in Bolivia, Correa in Ecuador or Lula da Silva in Brazil, aimed to reduce poverty in their countries, but in doing so they relied mainly on exports of natural resources, leading to the emergence of the term 'new extractivism.' One major component in this ongoing development was unquestionably the rise of China as a global industrial power. The $21^{\text {st }}$ century began with a global boom in demand for energy and natural resources. The terms of trade increasingly favored exports not only of raw materials like copper, tin, and oil but also agricultural products like soy, wheat, corn, and sugarcane. Hopes relating to national development once again began to rely on the extraction and exportation of natural resources. Furthermore, where conflicts occur, governments often tend to take the side of foreign companies against local communities and indigenous groups, who may be affected by environmental pressures due to mining, increasing land demand for agriculture, or fossil fuels extraction (Hogenboom 2012; Veltmeyer 2013). In the following section, the conditions in each country are analyzed in more detail.

\section{Argentina}

Raúl Alfonsín, who was elected president in 1983 immediately after the debt crisis, was not particularly enthusiastic about adhering to the Washington Consensus and responded to the debt crisis by implementing policies more in line with ISI than with structural adjustment. Towards the end of his legislative term, however, Argentina gradually opened its economy under considerable pressure from multilateral organizations. But it was not until Carlos Menem took over the presidency in 1989 that neoliberal economic reforms were more widely implemented (Kingstone 2012: 220). Moreover, the principal contribution to the surge in exports came from agriculture, where a transformation (often referred to as the 'Green Revolution') based on agrochemicals, hybrid seeds, and mechanization took place (Romero 2002).

After a decade of adhering to neoliberal doctrines, Argentina experienced an economic crisis of remarkable severity in 2001 (IMF 2004). According to Wylde (2012), the country faced the largest debt default the world had ever seen. From 2003, however, the GDP growth rate and exports increased again and the unemployment rate fell. A factor that contributed to the growth in exports was unquestionably the rise in

\footnotetext{
${ }^{5}$ Further neoliberal demands often involved: privatization, market deregulation, economic and trade liberalization, reduced government spending, austerity programs and export promotion.
} 
global commodity prices. In particular, China's and India's increasing impact on world demand created favorable terms of trade, at least temporarily, for Argentina's export economy.

\section{Bolivia}

Víctor Paz Estenssoro was elected president in 1985. "Forcefully backed by creditors", he steered Bolivia onto a clearly neoliberal pathway, which was presented as "the country's only salvation" (Webber 2011: 109). The debt crisis and the period of hyperinflation were used to justify the neoliberal restructuring of the 1980s and 1990s. Paz Estenssoro initiated a neoliberal revolution with the so-called New Economic Policy (NEP).

What followed was a story of repeated measures for austerity and liberalization. Under pressure from international lenders, Bolivia implemented reforms regarding inflation control, privatization, liberalization of trade and financial systems as well as other fiscal and monetary measures (Ascher and Mirovitskaya 2012).

But the privatization of key sectors had an unintended side-effect on the national economy: the state lost massive sources of income, especially from the hydrocarbon and mining sectors. Once these resources passed to private hands, the trickle-down effect to poorer social strata all but vanished. Ironically, the IMF then demanded cuts in expenditures on social security to make up for the budgetary shortfall (Hindery 2004; Webber 2011).

The so-called 'Water War' and 'Gas War' in 2003 emerged from massive demonstrations against further privatization plans. The resort to violent suppression of the protests forced the government to resign, thus paving the way for an anti-neoliberal movement that eventually led to the election of Evo Morales as president in 2006 (Postero 2010).

\section{Brazil}

The ISI strategy pursued in Brazil was comparatively successful in launching infant industries and diversifying the production sector, but it still faced the common difficulties of low competitiveness and a constantly growing need for imports of expensive capital goods (Kingstone 2012).

A fundamental commitment to a neoliberal ideology appeared relatively late in Brazil. Collor de Mello succeeded José Sarney as President of Brazil in 1990. To restore growth and restrict inflation, the new president established the liberal discourse of the Washington Consensus in Brazil. The familiar measures of opening the market for competition, promotion of foreign investments, and privatization soon provoked mass demonstrations, which forced Collor to resign. The implementation of the Real Plan in 1993 offered resolutions for a stable economy, the fight against inflation, and increasing economic liberalization (Lund and Klein 2006).

In 2003, Luís Inácio Lula da Silva, popularly known as 'Lula', finally achieved success in his fourth attempt to become president. Even before beginning his term, Lula had to make concessions to the economists and creditors to maintain economic stability and accept the IMF agreement (Wylde 2012: 137). In fact, Lula's socioeconomic policy was neither a revolutionary departure from the Washington Consensus doctrine nor strict adherence to it. For example, Lula promoted exports and rejected protectionism, but opposed further privatizations (Ban 2013).

\section{Results and discussion}

\section{Physical trade balances and export destinations}

Against the background of these macroeconomic structures, we will now present material flow data, in particular physical trade data, in order to provide a biophysical perspective of the Latin American economies. Presenting the biophysical exchange of Argentina, Bolivia, and Brazil with 'core' and 'non-core' countries against the backdrop of economic policies in these countries allows for a discussion of similarities and dissimilarities and thus possible causal links between the biophysical and the economic development of a country. The three countries examined are all net exporters of materials, indicated by a negative physical trade 
balance (PTB, see Figure 1) of 67 million tons in 2010 for Argentina, 9 million tons for Bolivia, and 374 million tons for Brazil. In the 1960s, 'core' countries were the main recipients of goods from South America. This had changed significantly by 2010, when only one-third or less of exported goods were moving to the 'core' countries.

In Argentina, major changes in the PTB coincide with changes in policy orientations. From 1962 to the late 1970s, trading intensity was rather low, which corresponded well with the inward-looking policy orientation at that time. During the 'lost decade' of the 1980s, the PTB gradually shifted to negative results, mainly due to shrinking imports. From the 1990s onwards, the country's PTB became more and more negative. Argentina remained a net importer of ores and minerals, but the net export of biomass products and fossil fuels increased dramatically. The greatest share of the biomass export category is primary crops, in particular cereals and fodder crops like maize and soybeans. Argentina's net imports consist mainly of iron ores, largely imported from Brazil. The opening of the economy changed Argentina's PTB into one that was increasingly negative: average net exports in the 1970s amounted to around 5 million tons per annum, while during the 1990s, these increased to more than 38 million tons, and in the 2000s reached an annual average of more than 70 million tons.

Bolivia's involvement in international trade is rather limited, both in terms of total volumes as well as per capita figures. International trade played a negligible role during the early 1960s. The 1970s brought an increase in fossil fuels exports, which resulted in a considerably negative mass balance. For almost three decades thereafter, Bolivia's foreign trade was characterized by moderate fossil fuels exports and a more or less negligible amount of physical imports. Interestingly, neither the end of ISI strategy, nor the Latin American debt crisis, nor the structural adjustment policy since 1985 is reflected in the PTB. No dramatic changes took place until the turn of the millennium. From then on, a massive increase in exports of natural gas and, to a lesser extent, petroleum can be observed. In addition, fodder crop production (mainly soybeans) was also progressively increased, largely for export.

Brazil is South America's largest economy and has acquired great importance on the world market. With its specialization on exports, Brazil is now an extractive economy that relies heavily on commodity sales in volatile international markets (Luna and Klein 2006; Wylde 2012). The country's PTB reflects this development: Brazil shifted from being a rather closed country into an open, export-oriented economy. The PTB indicates a low level of involvement in foreign trade in the 1960s. As in Argentina and Bolivia, ISI policies correspond well with physical trade balances. The 1970s were marked by a gradual abandonment of ISI and at the same time rising physical imports and exports. Until the 1980s, the PTB remained relatively balanced, and since then imports have remained relatively constant, whereas exports have increased significantly, resulting in a negative PTB. The main materials imported are fossil fuels, chemicals, and minerals for fertilizers. The major materials exported are iron ores and biomass in the form of primary and fodder crops (especially soybeans). Brazil's PTB turned conspicuously negative in the 1990s; this coincides with national policies that were implemented to open the economy. The same applied to the 2000s, where neoliberal governance and renewed extractivism was prevailing. In the future, this development trend may be challenging, since the export sector relies on favorable terms of trade and contributes to large shares of the GDP. Ban (2013: 321) notes that "the sustainability of growth hinges on external demand."

The graphs on the right hand side of Figure 1 show the changes in export destinations as a percentage of total exports. The export destinations were classified as 'core' if they belonged to the OECD (excluding Chile, Israel, Mexico and Turkey), while all other countries were grouped together as 'non-core' countries. To address the so-called China Effect (e.g. Hogenboom 2012; Veltmeyer 2013; Wylde 2012) and to highlight China's rise in the world economy we show the exports to China separately. China became the main export destination for Brazil, Chile, and Peru, and the second most important for countries like Argentina and Venezuela; it is thus now the major export destination for all resource-rich South American countries (Hogenboom 2012: $142 \mathrm{f}$.). 


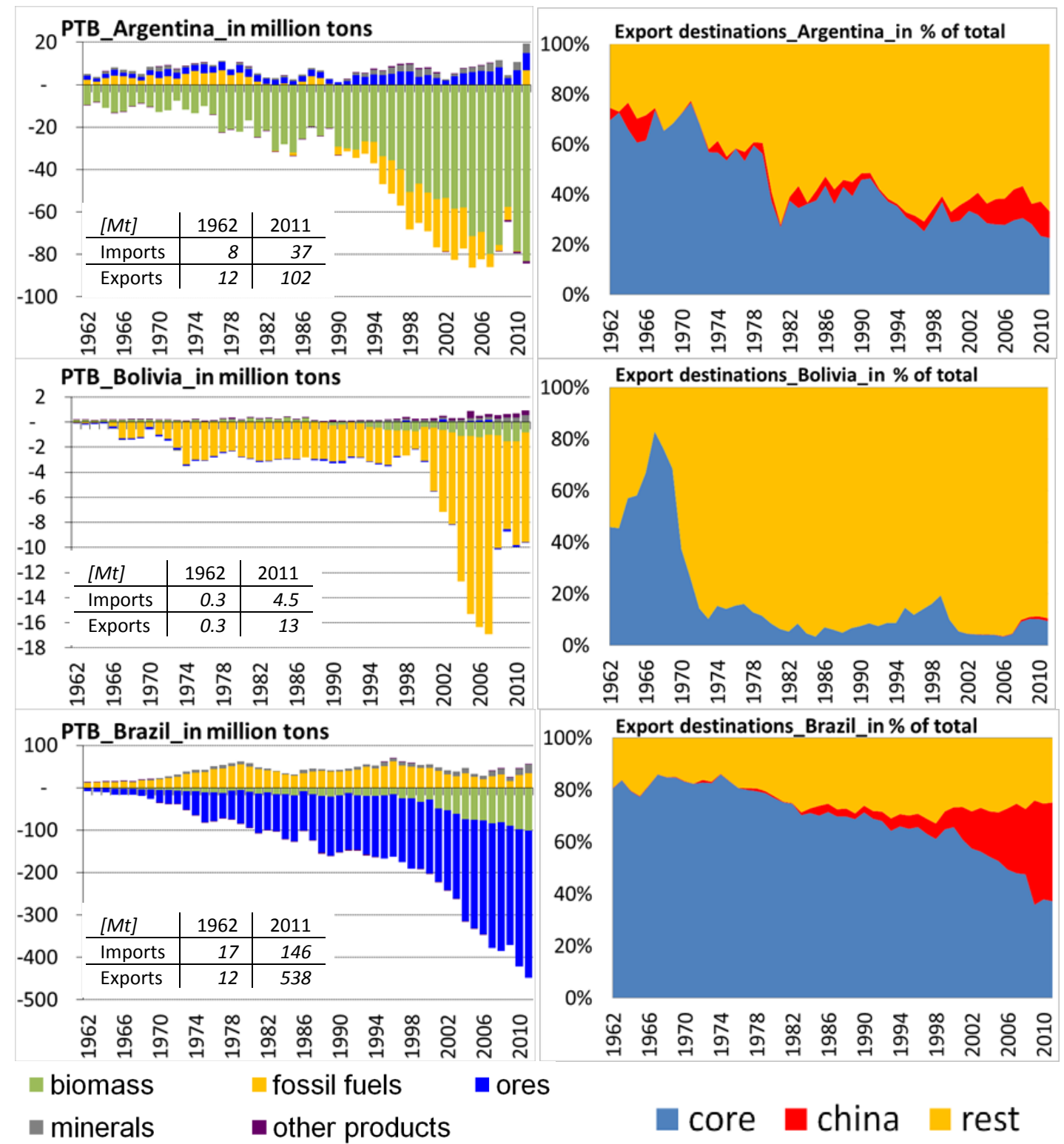

Figure 1: The physical trade balances (PTB) of Argentina, Bolivia, and Brazil in million metric tons (left), and the export destinations of physical goods from Argentina, Bolivia, and Brazil as a percentage of total exports (right) 1962-2011. As the PTBs display only net trade flows of each material category, the small tables inside the PTB graphs were included to show the total (pure) export and import figures as a sum of all material categories in the first and last year of the evaluation.

Bolivia has a different situation, where the 'core' is of minor importance among export destinations. One reason for this may be the fact that Bolivia is a landlocked country. Even though the 'core' received a high share of physical exports in the early 1960s (viz. crude petroleum to the USA), exports were mostly destined for 'non-core' countries, such as Bolivia's main trading partner Brazil. Moreover, the China Effect is 
hardly visible in Bolivia, where a mere $1 \%$ of material exports went to China in 2011. Regarding exports to the 'core', the USA is once again the main export destination.

Brazilian physical exports reveal a different pattern. Brazil had a strong bond with the 'core' in the late 1960s and early 1970s, with 86\% of its exports destined for 'core' countries. However, this proportion gradually decreased during the 1970s, 1980s, and 1990s. Finally, China replaced the 'core' as Brazil's main export destination in 2011, with the USA in second place. It must be noted, however, that a reduction in percentages does not imply a reduction in total volumes. In fact, these were growing, albeit not at the same pace as exports in general.

\section{The processing stage and average unit prices}

In debates about ecologically unequal exchange, the importance of the creation of entropy and the loss of potential energy is often discussed (cf. Bunker 2007). With regard to MFA data, we want to use information on the stage of processing of products to shed light on these issues. We used the detailed structure of the SITC classification scheme (Standard International Trade Classification, Rev. 3) of the United Nations Statistics Division (http://unstats.un.org). The SITC, Rev. 3, as it was used for compiling the PTBs, groups the reported goods into ten different categories. ${ }^{6}$ The first four categories ( 0 to 3 ) are classified as primary goods. The goods categorized as 4 to 9 contain secondary and finished goods. ${ }^{7}$ The classification of category 3 (mineral fuels) is problematic because it contains goods at different stages of processing from primary to more processed. An analysis of traded quantities at distinct levels within this category revealed that it included both primary and secondary goods, but in the case of Argentina, Bolivia, and Brazil trade in crude petroleum oils and natural gas clearly dominated. We finally classified SITC category 3 as primary goods, which is not unequivocal but nonetheless reasonable.

The following graphs (Figure 2) show the physical exports and imports of the three countries according to their stage of processing (primary or secondary/finished) and by their destination or origin ('core' or 'non-core'). It is important to note that the graphs are scaled differently.

As previously mentioned, Argentina mainly exports primary agricultural goods, both to 'core' and even more so to 'non-core' countries. The export of processed goods plays a minor role in terms of mass but is characterized by higher average unit price per ton as compared to the unit prices of primary products. The share of processed goods among Argentinean imports is higher, but the overall scale is much lower than for exports. Just as for the exports, imports are dominated by primary goods from 'non-core' countries. However, the imports of secondary and finished goods are considerable and have a much higher monetary value.

Bolivia mainly exports natural gas, which in this analysis is classified as a primary good. All other export categories are of minor importance. However, the secondary and finished goods have much higher average unit prices per ton. These include export commodities such as manufactured tin and other processed metals, which have a very high monetary value in relation to their mass. It is remarkable that Bolivia's imports consist of equal shares of primary and processed goods. However, the absolute quantities of imports are much lower (by a factor of 6 ) than exported mass.

\footnotetext{
${ }^{6} 0$ - Food and live animals; 1 - Beverages and tobacco; 2 - Crude materials, inedible, except fuels; 3 - Mineral fuels, lubricants, and related materials; 4 - Animal and vegetable oils, fats, and waxes; 5 - Chemicals and related products; 6 Manufactured goods, classified chiefly by material; 7 - Machinery and transport equipment; 8 - Miscellaneous manufactured articles; 9 - Commodities and transactions not classified elsewhere in the SITC.

${ }^{7}$ It must be noted that the distinction between primary and secondary/finished goods is only a rough approximation, as some categories may contain goods at different stages of production.
} 

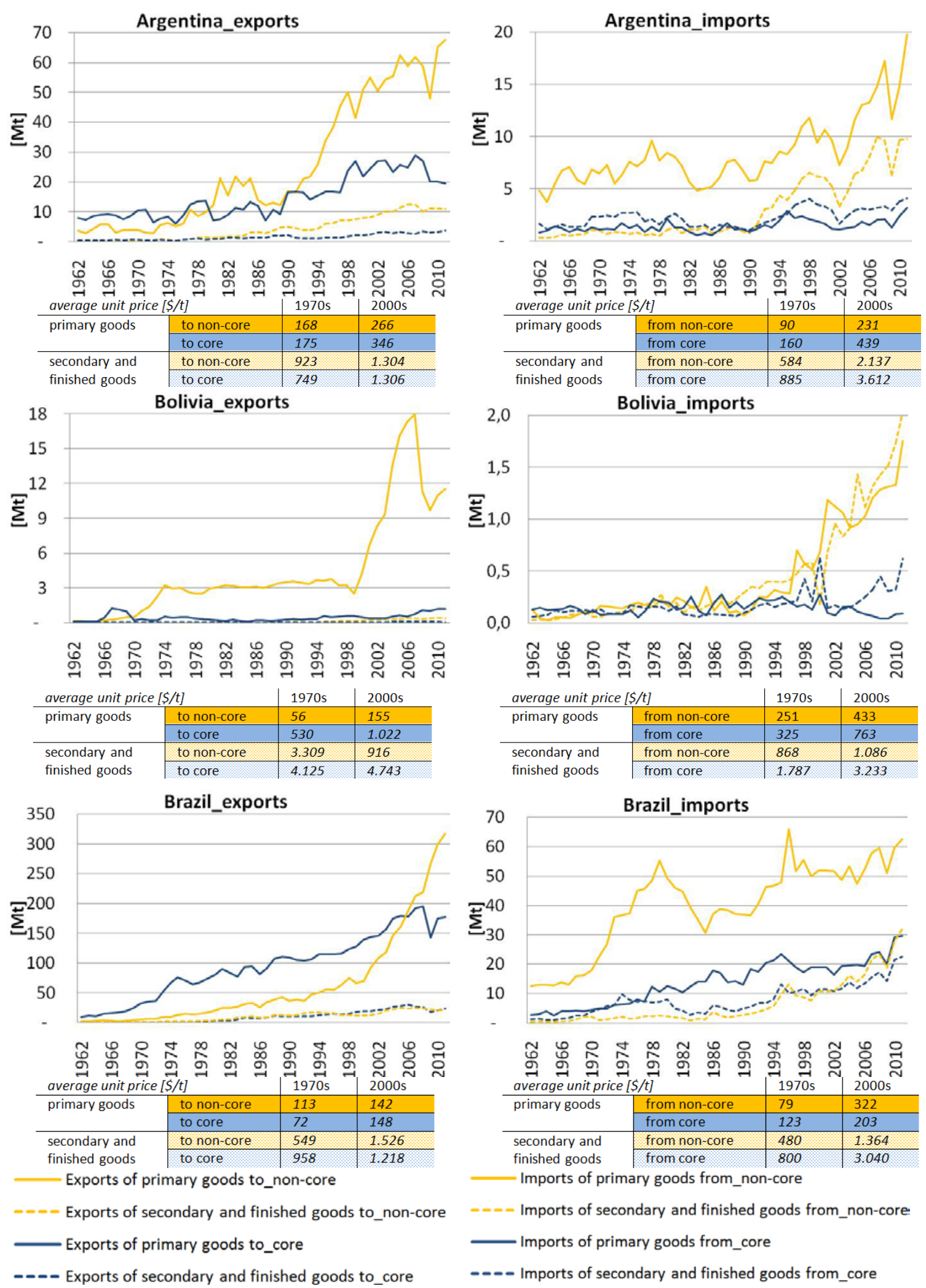

Figure 2: Physical exports and imports of Argentina, Bolivia, and Brazil according to their destination and origin ('core' or 'non-core') and their stage of processing (primary or secondary/finished) 1962-2011. The attached tables show the average unit prices in US\$ per ton for the time periods of the 1970s (1970-1979) and for the 2000s (2000-2009). 
Brazilian exports are also largely categorized as primary goods. These exports do not generate high revenues per ton as compared to the exports of secondary and finished products. The increasing exports to the 'core' were overtaken by exports destined for 'non-core' countries (mainly China). Interestingly, imports are also dominated by primary products (mainly fossil fuels). Nonetheless, processed goods play a more important role in imports than in exports.

\section{Physical and monetary trade balances}

In this section, we compare the PTBs with their respective monetary trade balances (MTB). The MTB is not identical to the national balance of trade, since no exchanges of services are included. The MTB data are based entirely on the current prices of the traded commodities reported to the UN Comtrade database. The graphs of Figure 3 illustrate the monetary deficits and profits that accompany the PTB. The primary axis (left) represents the PTB values in million tons per year, where all dark blue bars appearing below the zero line indicate a negative PTB. The MTB, indicated on the secondary axis on the right-hand side, represents the monetary values generated by the international trade in commodities. All orange bars below the zero line indicate a monetary deficit resulting from the physical exchange, and conversely, all bars above zero show the positive revenues gained from the physical exchange in a year. The graphs illustrate the different trade connections with 'core' and 'non-core' countries and thus illuminate relations of ecologically unequal exchange. Here, too, the graphs are scaled differently.

Argentina's involvement in international trade has markedly different features, depending on the trading partners. Regardless of the trading partners, the country's PTB has become increasingly negative over time, but while this has generated largely positive incomes from trade with 'non-core' countries, it did not do so in the trade with 'core' countries. While the PTB in relation to 'core' countries has become ever more negative, the corresponding MTB has not become positive to the same extent. This reveals that although Argentina has provided the 'core' with large amounts of physical goods, it has experienced a financial loss from this exchange. In other words, Argentina is reducing its natural capital without increasing its financial capital. In return for large quantities of low-value commodities (primary goods) delivered to the 'core', less bulky, more processed and high value-added products are imported from the 'core.'

The interpretation of Bolivia's data is more challenging. From 1970 to 2000, Bolivia's physical exchange with other countries stagnated at a very low level and yielded only a slightly positive or negative MTB. In relation to 'non-core' countries, the emerging new extractivism meant larger net exports and subsequently, with some years' delay, also a positive MTB. Bolivia's rising exports (mainly natural gas) generated external incomes of up to US\$1.2 billion in 2008. Data for Bolivia's trade with 'core' countries do not reveal a significant trend in any direction and remain at a very low level. Bolivia is the only country among the three examined that was able to generate a positive MTB and a corresponding positive PTB in relation to the 'core' at the same time, for example during the early 1980s. From 2004 onwards, the pattern changed significantly: the physical trade balance turns increasingly negative but the monetary trade balance is constantly improving. In having managed to achieve a net income of money by mainly exporting natural gas, Bolivia is thus a special case among the three countries we examined.

In the case of Brazil, by distinguishing foreign exchange into trade with 'core' and 'non-core' countries, respectively, we have found that Brazil was a net importer of physical goods from 'non-core' countries until the early 1980s, as was Argentina. In the early 1980s, Brazil became a net exporter of physical goods to noncore countries. The negative PTB is associated with a positive MTB. However, when it comes to trade with the 'core,' Brazil differs from the other two countries. First, the PTB has been negative since 1962 onwards. Second, for several years the MTB was negative too. In those years with negative trade balances for both physical and monetary trade, Brazil experienced a loss of natural as well as monetary capital, a clearly unfavorable situation. Only during the 1980s and early 1990s, before SAPs were implemented, and in the early 2000s, when the China Effect created more favorable terms of trade, was the MTB positive.

To sum up, both Argentina and Brazil have balanced their negative MTBs and financial losses through a more favorable exchange with 'non-core' countries. The deteriorating terms of trade in the late 2000s were particularly conspicuous in the MTBs of Argentina and Brazil in relation to 'core' countries. 

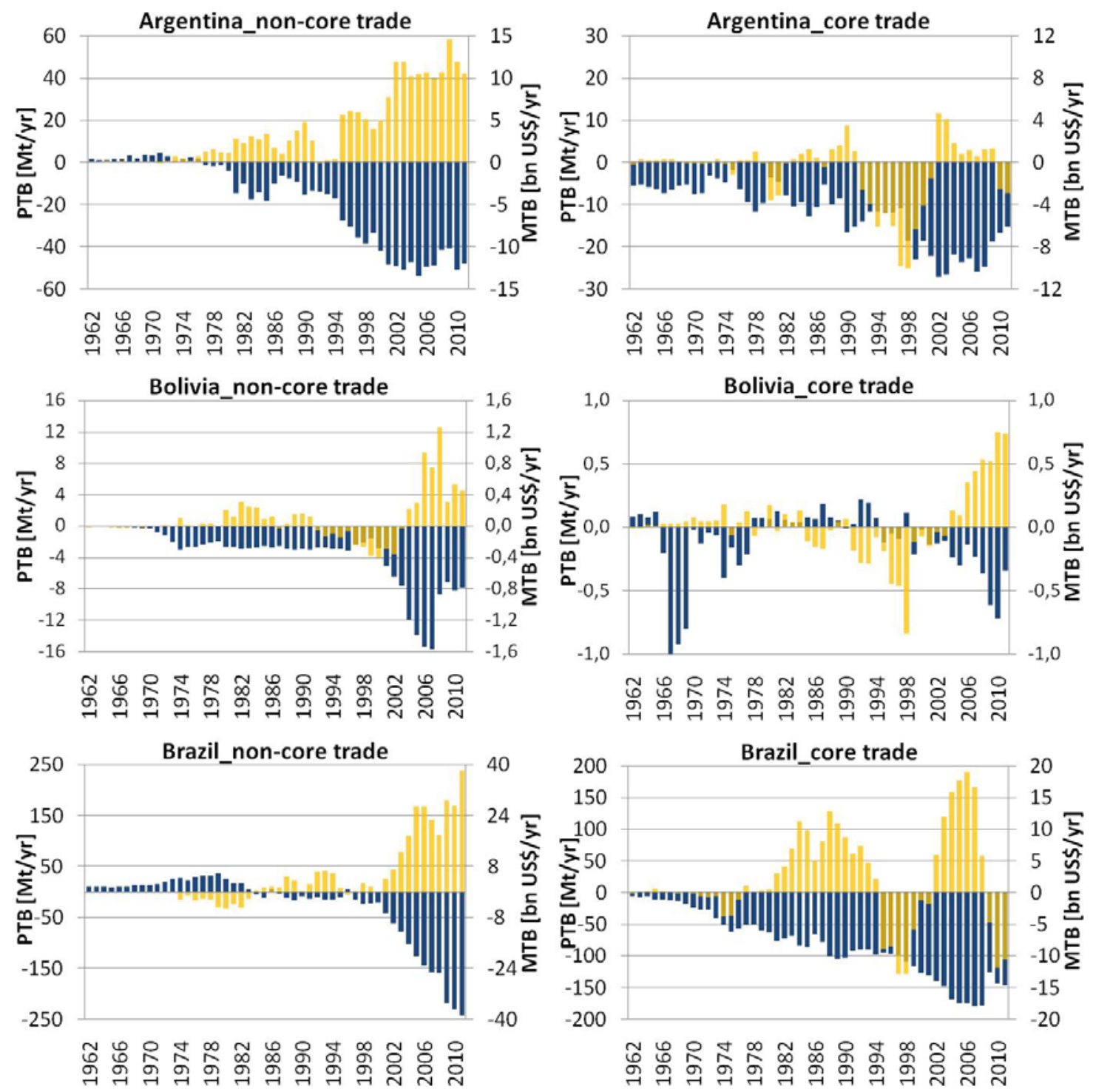

- Physical trade balance [Mt/yr]_primary y-axis

Monetary trade balance [bn US\$/yr]_secondary $y$-axis

Figure 3: Physical and monetary trade balances of Argentina, Bolivia, and Brazil 1962-2011. The graphs on the left display trade with 'non-core' countries, the graphs on the right trade with countries in the 'core'. Each graph shows the PTB in million tons per year on the primary axis (left) and the MTB in billion US\$ per year on the secondary axis (right).

\section{Conclusions}

In this article, we have investigated the physical trade relations of three South American countries: Argentina, Bolivia, and Brazil. All three countries are net exporters of physical goods and thus provide material resources for global markets. However, the countries' involvement in trade with 'core' and 'non-core' countries differs considerably. Taking into account the stage of processing of the traded commodities, average 
unit prices, and the MTB, many characteristics of an ecologically unequal exchange can be confirmed for these countries. Interestingly, it was precisely during the time of neoliberal adjustment that their MTBs as well as their PTBs deteriorated substantially, contradicting the explicit goals and promises of SAPs, which suggested that a liberalization of trade would result in foreign exchange earnings.

Especially during the 1990s, Argentina followed the typical development path predicted by theorists of the concept of ecologically unequal exchange. At that time, trade with 'core' countries resulted in a simultaneously negative physical and monetary balance indicating that Argentina was providing resources for other countries but at the same time not gaining money through trade. The data for Brazil point in a similar direction and trade with the 'core' has the worst mass-to-money ratio. Bolivia is something of an exception, due to lower total volumes of trade but with a strong focus on exporting fossil fuels (natural gas).

The data suggest that specialization in 'traditional' comparative advantages (e.g. resource endowment or perhaps a relatively low population density) may be a misleading foundation for the goal of achieving 'catch-up' development. All the three countries examined are characterized by strong net exports of primary products in physical terms. These massive exports of primary products challenge nature and humanity alike. Additionally, the average unit price of primary products is much lower as compared to secondary/finished goods and hence, processed goods obtain much higher prices on the global market per unit of weight. Biophysical extraction for exports does not yield positive financial trade balances in contexts where processed and higher-value goods need to be imported. Muradian and Martinez-Alier (2001) argue that peripheral, extractive economies face a "specialization trap" that deprives them of the opportunity to develop a higher degree of processing and generating higher revenues.

The new international political economy and the enforcement of free trade in South America in the 1980s and 1990s were described as "free trade imperialism" (Weaver 2000: 203). In relation to these trade structures, there have been numerous negative consequences for domestic ecosystems, biodiversity, and human populations. In South America, the clearing of tropical rainforests on a massive scale to create areas suitable for agriculture and cattle-grazing is the most apparent change. Furthermore, local consequences have often involved the creation of monocultures, soil depletion, and water pollution. The clearing of tropical rainforests threatens biodiversity in the most complex ecosystem on Earth, and often involves the displacement of indigenous peoples (Friedmann 2000). Rising domestic resistance to such development is, therefore, likely to continue.

\section{References}

Adriaanse, A., S. Bringezu, A. Hammond, Y. Moriguchi, E. Rodenburg, D. Rogich and H. Schütz. 1997. Resource flows: the material basis of industrial economies. Washington DC: World Resources Institute.

Ascher, W. and N. Mirovitskaya. 2012. Economic development patterns and the evolution of violence in Latin America. In W. Ascher and N. Mirovitskaya (eds.) Economic development strategies and the evolution of violence in Latin America. New York: Palgrave MacMillan. Pp. 1-40.

Babb, S. 2013. The Washington Consensus as transnational policy paradigm: its origins, trajectory and likely successor. Review of International Political Economy 20(2): 268-297.

Ban, C. 2013. Brazil's liberal neo-developmentalism: new paradigm or edited orthodoxy? Review of International Political Economy 20(2): 298-331.

Bulmer-Thomas, V. 1994. The economic history of Latin America since independence. Cambridge: Cambridge University Press.

Bunker, S.G. 1985. Underdeveloping the Amazon: extraction, unequal exchange, and the failure of the modern state. University of Chicago Press.

Bunker, S.G. 2007. Natural values and the physical inevitability of uneven development under capitalism. In A. Hornborg, J.R. McNeill and J. Martinez-Alier (eds.) Rethinking environmental history. worldsystem history and global environmental change. Lanham: AltaMira Press. Pp. 239-259. 
Cardoso, E. and A. Helwege. 1992. Latin America's economy: diversity, trends, and conflicts. Cambridge: MIT Press.

Dittrich, M. and S. Bringezu. 2010. The physical dimension of international trade: Part I: direct global flows between 1963 and 2005. Ecological Economics 69(9): 1838-1847.

European Union. 2011. Regulation (EU) No 691/2011 of the European Parliament and of the Council of 6 July 2011 on European environmental economic accounts. [accessed November 10 2014] http://eurlex.europa.eu/legal-content/EN/TXT/PDF/?uri=CELEX:32011R0691\&from=EN.

EUROSTAT. 2012. Economy-wide material flow accounts (EW-MFA). Compilation guide 2012. [accessed September $24 \quad$ 2013] $\quad$ http://epp.eurostat.ec.europa.eu/portal/page/portal/environmental_accounts/documents/Economy-wide\%20material\%20flow\%20accounts\%20compilation\%20guide\%20\%20-.pdf.

Fischer-Kowalski, M. and H. Haberl. 1998. Sustainable development: socioeconomic metabolism and colonization of nature. International Social Science Journal 158(4): 573-587.

Fischer-Kowalski, M. and H. Haberl. 2007. Socioecological transitions and global change: trajectories of social metabolism and land use. Cheltenham: Edward Elgar.

Fischer-Kowalski, M., F. Krausmann, S. Giljum, S. Lutter, A. Mayer, S. Bringezu, Y. Moriguchi, H. Schütz, H. Schandl and H. Weisz. 2011. Methodology and indicators of economy-wide material flow accounting: state of the art and reliability across sources. Journal of Industrial Ecology 15(6): 855-876.

Frank, A.G. 1966. The development of underdevelopment. Monthly Review 18(7): 17-31.

Friedmann, H. 2000. What on earth is the modern world-system? Foodgetting and territory in the modern era and beyond. Journal of World-System Research 11(2): 480-515. Researchgate

Furtado, C. 2007 [1959]. Formação econômica do Brasil. São Paulo: Companhia das Letras.

Giljum, S. and N. Eisenmenger. 2004. North-south trade and the distribution of environmental goods and burdens: a biophysical perspective. Journal of Environment and Development 13(1): 73-100.

Hogenboom, B. 2012. Depoliticized and repoliticized minerals in Latin America. Journal of Developing Societies 28(2): 133-158.

Hornborg, A. 1998. Towards an ecological theory of unequal exchange: articulating world system theory and ecological economics. Ecological Economics 25: 127-136.

Hornborg, A. 2007. Introduction: environmental history as political ecology. In Hornborg, A., J.R. McNeill and J. Martinez-Alier (eds.) Rethinking environmental history: world-system history and global environmental change. Lanham: AltaMira Press. Pp. 1-24.

Hornborg, A. 2010. Uneven development as a result of the unequal exchange of time and space: some conceptual issues. Journal für Entwicklungspolitik 26(4): 36-56. (Special issue edited by S.J. Singh and B. Köhler)

Hornborg, A. 2012. Global ecology and unequal exchange: fetishism in a zero-sum world. London and New York: Routledge.

IMF. 2004. The IMF and Argentina, 1991-2001. Evaluation Report. [accessed November 13 2013] http://www.imf.org/External/NP/ieo/2004/arg/eng/pdf/-report.pdf.

Jorgenson, A. K. and C. Brett. 2009. The economy, military, and ecologically unequal exchange relationships in comparative perspective: a panel study of the ecological footprints of nations, 1975-2000. Social Problems 56(4): 621-646. Academia

Kingstone, P. 2012. Economic exclusion and the shifting patterns of violence in Argentina and Brazil. In W. Ascher and N. Mirovitskaya (eds.) Economic development strategies and the evolution of violence in Latin America. New York: Palgrave MacMillan. Pp. 213-250.

Luna, F. and H. Klein. 2006. Brazil since 1980. Cambridge: Cambridge University Press.

Martinez-Alier, J. 1987. Ecological economics: energy, environment and society. Cambridge: Basil Blackwell. 
Martinez-Alier, J. 2002. The environmentalism of the poor: a study of ecological conflicts and valuation. Cheltenham: Edward Elgar. Ch.1,2

Martinez-Alier, J. 2007. Marxism, social metabolism, and international trade. In Hornborg, A., J.R. McNeill, and J. Martinez-Alier (eds.) Rethinking environmental history: world-system history and global environmental change. Lanham: AltaMira Press. Pp. 221-237.

Matthews, E., C. Amann, S. Bringezu, M. Fischer-Kowalski, W. Hüttler, R. Kleijn, Y. Moriguchi, C. Ottke, E. Rodenbug, D. Rogich, H. Schandl, H. Schütz, E. van der Voet and H. Weisz. 2000. The weight of nations: material outflows from industrial economies. Washington D.C.: World Resource Institute.

Muradian, R. and J. Martinez-Alier. 2001. Trade and the environment: from a 'Southern' perspective. Ecological Economics 36: 281-297.

OECD. 2008. Measuring material flows and resource productivity: volume I. The OECD Guide. [accessed November 10 2014] http://www.oecd.org/environment/indicators-modelling-outlooks/MFA-Guide.pdf.

Postero, N. 2010. The struggle to create a radical democracy in Bolivia. Latin American Research Review 45: 59-78.

Prebisch, R. 1949. The economic development of Latin America and its principal problems. New York: United Nations Department of Economic Affairs.

Rice, J. 2007. Ecological unequal exchange: international trade and uneven utilization of environmental space in the world system. Social Forces 85(3): 1369-1392.

Romero, L.A. 2002. A history of Argentina in the twentieth century. Pennsylvania: Pennsylvania State University Press.

Schütz, H., S. Moll and S. Bringezu. 2004. Globalisation and the shifting environmental burden: material trade flows of the European Union. Wuppertal Papers 134e. Wuppertal: Wuppertal Institute for Climate, Environment, Energy.

Scott, B.R. 2011. Capitalism: its origins and evolution as a system of governance. New York: Springer.

United Nations. 2014. System of environmental-economic accounting 2012. Central framework. [accessed November 10 2014] http://unstats.un.org/unsd/envaccounting/seeaRev/SEEA_CF_Final_en.pdf.

Veltmeyer, H. 2013. The political economy of natural resource extraction: a new model or extractive imperialism? Canadian Journal of Development Studies 34(1): 79-95.

Wallerstein, I. 1974. The modern world-system, vol. I: capitalist agriculture and the origins of the European world-economy in the sixteenth century. New York/London: Academic Press.

Wallerstein, I. 1980. The modern world-system, vol. II: mercantilism and the consolidation of the European world-economy, 1600-1750. New York: Academic Press.

Wallerstein, I. 1989. The modern world-system, vol. III: the second great expansion of the capitalist worldeconomy, 1730-1840s. San Diego: Academic Press.

Wallerstein, I. 2000. Globalisation or the age of transition: a long-term view of the trajectory of the world system. International Sociology 15(2): 249-265.

Weaver, F. 2000. Latin America in the world economy: mercantile colonialism to global capitalism. Boulder: Westview Press.

Webber, J. 2011. Red October: left-indigenous struggles in modern Bolivia. Leiden: Brill.

Weisz, H. and H. Schandl. 2008. Materials use across world regions: inevitable pasts and possible futures. Journal of Industrial Ecology 12(5/6): 629-636.

Wiedmann, T. O., H. Schandl, M. Lenzen, D. Moran, S. Suh, J. West and K. Kanemoto. 2013. The material footprint of nations. Proceedings of the National Academy of Sciences 112(20): 6271-6276.

Wylde, C. 2012. Latin America after neoliberalism: developmental regimes in post-crisis states. Basingstoke: Palgrave MacMillan. 